\title{
Body size of Chilean foxes: a new pattern in light of new data
}

\author{
Jaime E. JIMÉNEZ*, José L. YÁÑEZ, Elier L. TABILO, \\ and Fabián M. JAKSIĆ
}

\begin{abstract}
Jiménez J. E., Yáñez J. L., Tabilo E. L. and Jaksić F. M. 1995. Body size of Chilean foxes: a new pattern in light of new data. Acta Theriologica 40: 321-326.

By using body measurements and weight data of culpeo fox Dusicyon culpaeus Molina, 1782 and chilla fox D. griseus Gray, 1837 from the Chinchilla National Reserve (north-central Chile) and Torres del Paine National Park (southern Chile), the body size distribution of Chilean foxes was analyzed and compared to data previously published by Fuentes and Jaksić (1979). Contrary to those authors, our data show that not only the larger but both species increase in size in southern Chile. Thus, latitudinal size distribution of $D$. culpaeus and $D$. griseus may not be the result of character displacement through exploitation competition, as previously interpreted, but of bioenergetic adaptations.

Department of Wildlife Ecology and Conservation, University of Florida, Gainesville, FL 32611, USA (JEJ); Sección Zoología, Museo Nacional de Historia Natural, Casilla 787, Santiago, Chile (JLY); Proyecto Chinchilla, Corporación Nacional Forestal, Vicuña Mackenna 93, Illapel, Chile (ELT); Departamento de Ecología, Pontificia Universidad Católica de Chile, Casilla 114-D, Santiago, Chile (FMJ)
\end{abstract}

Key words: Dusicyon culpaeus, Dusicyon griseus, Canidae, body size, sympatric foxes, Chile

\section{Introduction}

Culpeos Dusicyon culpaeus Molina, 1782 and chillas D. griseus Gray, 1837 are widely distributed throughout western South America (Ginsberg and MacDonald 1990). D. culpaeus is larger, and found along the Andes from southern Colombia (Nariño Province, E. Barriga, pers. comm.) to Magallanes in southern Chile, including the island of Tierra del Fuego. D. griseus has a more restricted distribution and inhabits the lowlands of Chile and Argentina from 25 degrees south (Sheldon 1992, but see Marquet et al. 1993). D. griseus was introduced into Tierra del Fuego in 1951 to control European rabbit infestations (Jaksić and Yáñez 1983). Generally, D. culpaeus inhabits mountains, rugged terrain, or forested habitats, whereas D. griseus is associated with lowlands and open areas (Osgood 1943, Greer

\footnotetext{
* Present address: Department of Fisheries and Wildlife, Utah State University, Logan, UT 84322-5210, USA
} 
1965). Despite their extensive and broadly overlapping ranges, D. culpaeus and D. griseus are usually allopatric. Johnson (1992) and Jiménez (1993), however, working in southern and north-central Chile, respectively, found sympatric populations of $D$. griseus and $D$. culpaeus to partition habitat at a microhabitat scale.

Based on the distributional pattern of $D$. culpaeus and $D$. griseus from $33^{\circ} \mathrm{S}$ to $53^{\circ} \mathrm{S}$ along Chile, Fuentes and Jaksić (1979) tested the hypothesis of niche-complementarity (Schoener 1974) between diet and habitat to explair the distributions and body sizes of these foxes. Fuentes and Jaksić (1979) examined body length data of $D$. culpaeus and $D$. griseus and found that foxes in northern Chile, where they were supposedly allopatric, had more similar body sizes. Toward their southern ranges, however, $D$. culpaeus and $D$. griseus became sympatric and were found to diverge in body size. Fuentes and Jaksić (1979) implied that the high elevation of the Andes in the north allowed the foxes to partition habitat altitudinally. As the Andes decreased in altitude toward the south, no such segregation was possible, and competition by sympatric foxes for food thus led to displacement in body size. This model of niche complementarity has never been tested again.

Here, the body size pattern of $D$. culpaeus and $D$. griseus at both extremes of Fuentes and Jaksićs (1979) gradient was examined. The robustness of Fuentes and Jaksićs model for body size of $D$. culpaeus and $D$. griseus was tested by comparing new data from north-central Chilean foxes with those from southern Chile. Specifically, the null hypothesis that both foxes have equal body sizes in northern and southern Chile was tested, against the alternative hypothesis that $D$. culpaeus and $D$. griseus diverge in body size in comparison to their northern counterparts.

\section{Methods}

Data for sympatric $D$. culpaeus and $D$. griseus from both the Chinchilla National Reserve a: Aucó ( $31^{\circ} 30^{\prime}$ S, $71^{\circ} 06^{\prime}$ W, north-central Chile) and from Torres del Paine National Park (51 $033^{\prime}$ S, 72 $55^{\prime}$ ' W, southern Chile) was obtained. Detailed descriptions of these sites are found, respectively, in Jinénez (1993) and Johnson and Franklin (1994).

Foxes were trapped at Aucó with 1.5 padded leg-hold traps from January to August 1992. Captured D. culpaeus and D. griseus were measured and weighed. As measures of body size body mass, body length (head + trunk), and total body length (body length + tail) were used. For the southern locality Johnson's data (1992, and unpublished data) were used. He used the same field techniques and metrics as in the Aucó study.

\section{Data analyses}

Data from adult foxes only were analyzed and tested for differences in body size by species between the two localities. Bootstrap analyses (Efron and Gong 1983, Noreen 1989) were performed, because they are more powerful than other standard methods for this small and unbalanced dita set (Potvin and Roff 1993). Essentially, what bootstrapping does is to take random samples from the original sample considering that the null hypothesis is true. The samples are taken indepencently, 
with replacement, and each value has the same probability of being sampled. This procedure is repeated many times and every time a test statistic is calculated from the pseudosamples. These statistics (which have a normal distribution) are plotted as a frequency distribution. The hypotheses are tested by comparing the statistic computed on the real sample against the simulated distribution generated by bootstrapping (Noreen 1989). According to the hypothesis being tested, the critical region is represented by either of tails of the simulated distribution.

The samples were bootstrapped 500 times in Minitab (Ryan et al. 1985) and pooled $t$-tests (Ott 1988) were computed with a program written for the same statistical package (see Appendix). The critical region for the $5 \%$ level was represented by the 25 most extreme values out of the 500 computed (on the upper tail for $\mathrm{H}_{\mathrm{a}}: \mu_{1}>\mu_{2}$ and vice versa).

\section{Results and discussion}

Data from $9 \mathrm{D}$. culpaeus and $16 \mathrm{D}$. griseus from Aucó and $7 \mathrm{D}$. culpaeus and $36 \mathrm{D}$. griseus from Torres del Paine were analyzed. $D$. culpaeus from Torres del Paine were substantially larger (ie heavier and longer) than those from Aucó (Table 1). D. griseus from Torres del Paine were also larger than those from Aucó. These results were consistent for the three body size estimators in all the tests performed (Table 1). The fact that all three body size estimators showed the same pattern should not be surprising because they are probably correlated among each other. Thus, the new data differ markedly from those presented by Fuentes and Jaksić (1979).

Our analysis indicates that both $D$. culpaeus and $D$. griseus increase in size toward the south (Table 1). D. culpaeus and D. griseus had the same head and body length ratios (Fuentes and Jaksić's size estimator) at the two latitudes examined (1.224 for Aucó and 1.227 for Torres del Paine). For the cubic root of the weights, the ratio for Torres del Paine foxes was somewhat larger than for Aucó foxes (1.408 vs 1.201). Therefore, both foxes diverge in body weight, but only

Table 1. Size relations of sympatric Dusicyon culpaeus and D. griseus in northern (Aucó) and southern (Torres del Paine) Chile. Comparisons between means were performed by bootstrapping pooled $t$-tests ( $p$-values shown). Body length is the length of head + body, total length includes the length of the tail. Length measurements are in mm and weight in g. ${ }^{a}$ This paper and Jiménez (1993), ${ }^{b}$ this paper and Johnson (1992).

\begin{tabular}{|c|c|c|c|c|c|c|c|c|}
\hline \multirow{2}{*}{ Variable } & \multicolumn{3}{|c|}{ Aucó $^{\mathrm{a}}$} & \multicolumn{3}{|c|}{ Torres del Paine ${ }^{b}$} & \multirow{2}{*}{$\begin{array}{l}\mathrm{H}_{0}: \mu_{1}=\mu_{2} \\
\mathrm{H}_{\mathrm{a}}: \mu_{1}>\mu_{2}\end{array}$} & \multirow{2}{*}{$\begin{array}{l}\mathrm{H}_{0}: \mu_{1}=\mu_{2} \\
\mathrm{H}_{\mathrm{a}}: \mu_{1}<\mu_{2}\end{array}$} \\
\hline & $n$ & Mean & SE & $n$ & Mean & $\mathrm{SE}$ & & \\
\hline \multicolumn{9}{|l|}{ D. culpaeus } \\
\hline Body weight & 9 & 4316.7 & 207.8 & 7 & 10157.1 & 848.8 & & $<0.002$ \\
\hline Body length & 9 & 628.3 & 20.5 & 7 & 739.3 & 50.7 & & $<0.020$ \\
\hline Total length & 9 & 999.4 & 18.5 & 7 & 1152.1 & 45.4 & & $<0.008$ \\
\hline \multicolumn{9}{|l|}{ D. griseus } \\
\hline Body weight & 16 & 2495.0 & 86.4 & 35 & 3640.0 & 87.9 & $>0.998$ & $<0.002$ \\
\hline Body length & 16 & 513.4 & 9.4 & 36 & 602.4 & 8.5 & $>0.998$ & $<0.002$ \\
\hline Total length & 16 & 824.4 & 13.6 & 36 & 938.6 & 11.3 & $>0.998$ & $<0.002$ \\
\hline
\end{tabular}


because $D$. culpaeus is substantially heavier than $D$. griseus in Torres del Paine. This result is only in partial accord with Fuentes and Jaksić's (1979) report that as $D$. culpaeus increased in size, $D$. griseus decreased.

The increase in body size toward higher latitudes, as shown by $D$. culpaeus and $D$. griseus, is the expected pattern under Bergmann's rule, which states that ".. foxes, deer, and other mammals with a wide distribution are often larger in colder areas..." (Begon et al. 1990: 65). Therefore, the body size pattern of Chilean foxes may not be a consequence of exploitation competition as previously proposed by Fuentes and Jaksić (1979) but the by-product of their respective adjustments to living in colder regions. Interference competition, however, has been described to occur at both sites, were $D$. culpaeus excludes $D$. griseus from the best (prey-wise) habitat patches (Jiménez 1993, Johnson and Franklin 1994). The hypothesis that the larger southern foxes are faced to a larger spectrum of prey sizes than the smaller northern foxes is appealing and awaits testing.

In order to corroborate the data sets, we surveyed published data on the same species and sent interviews to 31 South American researchers and museum curators. Only $10(32.3 \%)$ responded, all stating that they had no data available at that time.

Few other data could be found in the literature. Body weight data for $D$. culpaeus were found in Crespo and De Carlo (1963; mean $=8177.5 \mathrm{~g}, n=195$, Neuquén Province, Argentina, 39 33'S), in Jaksić et al. (1993; mean $=6520 \mathrm{~g}, \mathrm{SD}$ $=3019 \mathrm{~g}, n=5$, Fray Jorge, Chile, 30 38'S), and in Greer (1965; Malleco, Chile, $\left.38^{\circ} \mathrm{S}\right)$. Both Crespo and De Carlo's (1963) and Greer's (1965) data, as well as those of one D. culpaeus from Cunco (Chile, $39^{\circ} 00^{\prime} \mathrm{S}, 7750 \mathrm{~g}$, B. Guiñez, pers. comm.) were intermediate between the values here reported for Aucó and Torres del Paine. However, D. culpaeus data from intermediate localities appear above the lines that connect the extreme values. This suggests that the change in body size may not be a linear function of latitude. An alternative view is that $D$. culpaeus are unexpectedly small for the latitude at Aucó. This speculation is substantiated when calculating the ratio for the cube root of weights between Fray Jorge $D$. culpaeus and Aucó D. griseus (1.378), which is surprisingly close to that for Torres del Paine foxes (1.408).

Because $D$. griseus is absent from Fray Jorge (at approximately $150 \mathrm{~km} \mathrm{NW}$ of Aucó), the large body size of allopatric $D$. culpaeus there compared to $D$. culpaeus at Aucó, is not explained by competition theory. Fray Jorge appears to be an interesting site to study $D$. culpaeus ecology.

Finally, the foxes at Aucó departed from the pattern depicted by Fuentes and Jaksić (1979) in two other ways. First, at Aucó D. culpaeus and D. griseus are sympatric though not syntopic (ie showed different habitat preferences). Thus, these two foxes are not altitudinally segregated at least in this study site. This scenario of coexisting $D$. culpaeus and $D$. griseus in northern Chile was not contemplated in Fuentes and Jaksićs model. Second, Aucó foxes also differ in their diets (Jiménez 1993), contrary to the predictions of the model. Whether the 
sympatric Aucó foxes constitute a unique case, or represent a common situation in northern Chile, remains to be investigated.

Acknowledgements: This research was supported by grants from the Lincoln Park Scott Neotropic Fund, and Program for Studies in Tropical Conservation from the University of Florida to J. E. Jiménez, and from Fondo Nacional de Investigación Científica y Tecnológica (FONDECYT 92-0038) to J. L. Yáñez. We acknowledge the Chilean Forest Service (CONAF) for their logistic support and for allowing us to work in the Chinchilla National Reserve. We are grateful to W. E. Johnson for kindly providing unpublished data, and to C. Muñoz and B. Saavedra for their assistance in the field. Responses from L. Albuja, E. Barriga, L. A. Coloma, M. H. Gallardo, A. Muñoz, J. Salazar, E. Suárez, S. Tiranti, O. Vaccaro, and G. Zunino are appreciated. J. E. Jiménez thanks J. P. Jorgenson, P. Meyers, O. P. Pearson, K. H. Redford, R. Ward, and two anonymous reviewer for their comments on earlier drafts and R. Canfield for statistical advise. He co-wrote this paper while holding a Quinney Fellowship from Utah State University.

\section{References}

Begon M., Harper J. L. and Townsend C. R. 1990. Ecology: individuals, populations and communities. Blackwell Scientific Publications, Boston: 1-945.

Crespo J. A. and De Carlo J. M. 1963. Estudio ecológico de una población de zorros colorados, Dusicyon culpaeus culpaeus (Molina) en el oeste de la provincia de Neuquén. Revista del Museo Argentino de Ciencias Naturales Bernardino Rivadavia, Ecología 1: 1-55.

Efron B. and Gong G. 1983. A leisurely look at the bootstrap, the jackknife, and cross-validation. American Statistician 37: 36-48.

Fuentes E. R. and Jaksić F. M. 1979. Latitudinal size variation of Chilean foxes: test of alternative hypotheses. Ecology 60: 43-47.

Ginsberg J. R. and MacDonald D. W. 1990. Foxes, wolves, jackals, and dogs. An action plan for the conservation of canids. IUCN/SSC canid and wolf specialist groups, Cambridge, United Kingdom: $1-116$.

Greer J. K. 1965. Mammals of Malleco Province, Chile. Publications of the Museum, Michigan State University, Biological Series 3: 51-151.

Jaksić F. M. and Yáñez J. L. 1983. Rabbit and foxes introductions in Tierra del Fuego: history and assessment of the attempts at biological control of the rabbit infestation. Biological Conservation 26: $367-374$.

Jaksić F. M., Meserve P. L., Gutiérrez J. L. and Tabilo E. L. 1993. The components of predation on small mammals in semiarid Chile: preliminary results. Revista Chilena de Historia Natural 66: $305-321$.

Jiménez J. E. 1993. Comparative ecology of Dusicyon foxes at the Chinchilla National Reserve in northcentral Chile. M Sc thesis, University of Florida, Gainesville: 1-168.

Johnson W. E. 1992. Comparative ecology of two sympatric South American foxes Dusicyon griseus and D. culpaeus. Ph D thesis, Iowa State Univ., Ames: 1-142.

Johnson W. E. and Franklin W. L. 1994. Role of body size in the diets of sympatric gray and culpeo foxes. Journal of Mammalogy 75: 163-174.

Marquet P. A., Contreras L. C., Torres-Mura J. C., Silva S. I. and Jaksić F. M. 1993. Food habits of Pseudalopex foxes in the Atacama desert, pre-Andean ranges, and the high Andean plateau of northernmost Chile. Mammalia 57: 130-135.

Noreen E. W. 1989. Computer intensive methods. John Wiley and Sons, New York: 1-229.

Osgood W. H. 1943. The mammals of Chile. Field Museum of Natural History, Zoological Series 30 : $1-268$.

Ott L. 1988. An introduction to statistical methods and data analysis. Third ed. PWS-Kent Publishing Co., Boston: 1-835. 
Potvin C. and Roff D. A. 1993. Distribution-free and robust statistical methods: viable alternatives to parametric statistics? Ecology 74: 1617-1628.

Ryan B. F., Joiner B. L. and Ryan T. A., Jr 1985. Minitab handbook. Second ed. PWS-Kent Publishing Co., Boston: 1-379.

Schoener T. W. 1974. Resource partitioning in ecological communities. Science 185: 27-39.

Sheldon J. W. 1992. Wild dogs: the natural history of the nondomestic Canidae. Academic Press, San Diego: 1-248.

Received 19 January 1995, accepted 28 June 1995.

Appendix. Minitab program used for bootstrapping. The program selects $\mathrm{n} 1$ and $\mathrm{n} 2$ random numbers with replacement from the pooled original data, which were in C1. Each datum was selected with equal probability $(1 /(\mathrm{n} 1+\mathrm{n} 2))$ in $\mathrm{C} 2$. The program computes a pooled $t$-test. This procedure was repeated 500 times with each data set. The statistics were stored in $\mathrm{C} 6$ after being sorted in ascending order. The variables $\mathrm{n} 1$ and $\mathrm{n} 2$ were the sample sizes.

\author{
NOECHO \\ LET K1=n1 \\ LET K2=n2 \\ RANDOM K1 C3; \\ DISCRETE C1 C2. \\ RANDOM K2 C4; \\ DISCRETE C1 C2. \\ LET K3=MEAN(C3) \\ LET K4=MEAN(C4) \\ LET K5=K3-K4 \\ LET K6=STDEV(C3) \\ LET K7=STDEV(C4) \\ LET K6=K6 $\times \mathrm{K} 6$ \\ LET K7=K7 $\times$ K7 \\ LET $\mathrm{K} 8=\mathrm{K} 1+\mathrm{K} 2-2$ \\ LET K9 $=(\mathrm{K} 1-1) \times \mathrm{K} 6+(\mathrm{K} 2-1) \times \mathrm{K} 7$ \\ LET $\mathrm{K} 10=\mathrm{K} 9 / \mathrm{K} 8$ \\ LET K11=SQRT(K10) \\ LET K12=(1/K1)+(1/K2) \\ LET K13=SQRT(K12) \\ LET K14=K5/(K11×K13) \\ STACK K14 C5 C5 \\ SORT C5 C6 \\ END
}

